\title{
Meningkatkan Minat Membaca Pada Anak Usia Sekolah Dasar Melalui Program Tayangan Televisi Dalam Perspektif Sosiologi
}

\author{
Bakhtiyar', Imas Rahmadhtul Hidayah² \\ Jurusan Ilmu Perpustakaan Universitas Wijaya Kusuma Surabaya \\ Email : bakhtiyar.fisipuwks@gmail.com
}

\begin{abstract}
The study aims to describe (1). The role of parents fostering interest in reading elementary school age children through television programs. (2). The positive impact of the TV program "Tau Gak Sih" on the development of reading interest in elementary school age children. The research is objecting to a comprehensive detailed study of the main content, the role of parents in assisting watching television programs to foster interest in reading. The scope of the study includes analysis-based analysis activities, focusing on the role of managing elementary school children's interest in reading by assisting learning. Analysis requires realistic critical thinking to apply conceptualization, so that it uses a historical approach characterized by realistic critical inquiry into the development of a thought. Primary information sources are used as primary data. The technique of collecting data utilizes library research, which is reading various kinds of literature. The analysis was conducted descriptively qualitative, sourced from theoretical reading material, research and not research. The validity of the research can be achieved by utilizing content analysis, in order to analyze the meaning, the role of parents, the function of the family in developing interest in reading elementary school-age children through TV programs. Observation is used as an element to support the construction of the theory. The results of the study include; (1) Parents play an important role in providing assistance in fostering elementary school-age children's interest in reading through television programs. (2) The positive impact of the TV program "Tau Gak Sih" on the development of reading interest in elementary school age children is as a medium of learning, expanding knowledge and motivating reading activities
\end{abstract}

Keywords: Children; Interest in Reading; The role of parents; Television program shows

\begin{abstract}
Abstrak
Penelitian bertujuan mendiskripsikan (1). Peranan orang tua menumbuhkembangkan minat membaca anak usia Sekolah Dasar dengan melalui program tayangan televisi. (2). Dampak positif program TV "Tau Gak Sih" terhadap pengembangan minat baca anak usia Sekolag Dasar. Research berobyekan kajian komprehensif detail mengenai content utama, peran orang tua dalam pendampingan menonton program tayangan televisi untuk menumbuhkembangkan minat baca. Ruang lingkup penelitian berlingkupkan aktivitas penganalisaan berbasis pemfokusan kajian, terhadap peranan memenej minat baca anak Sekolah Dasar dengan melakukan pendampingan belajar. Penganalisaan membutuhkan pemikiran kritis realitis mengaplikasikan konseptualisasi, sehingga menggunakan historical approach berkarakteristika penyelidikan kritis realitis terhadap perkembangan suatu pemikiran. Sumber informasi primer dipergunakan sebagai data primer. Teknik
\end{abstract}


menghimpun data mendayagunakan library research, yakni membaca bermacam-macam literatur. Analisa dilakukan secara diskriptif kualitatif, bersumber bahan bacaan teoritik, research serta bukan research. Validitas penelitian bisa tercapai dengan pendayagunaan content analysis, guna menganalisa makna, peranan orang tua, fungsi keluarga dalam menumbuhkembangkan minat baca anak usia Sekolah Dasar melalui program tayangan TV. Observasi dimanfaatkan sebagai unsur menunjang pengkontruksian teori. Hasil penenlitian meliputi; (1) Orang tua berperan penting melakukan pendampingan menumbuhkembangkan minat baca anak usia Sekolah Dasar melalui program tayangan televisi. (2) Dampak positif program TV "Tau Gak Sih" terhadap pengembangan minat baca anak usia Sekolah Dasar adalah sebagai media belajar, memperluas pengetahuan maupun memotivasi melakukan aktivitas membaca.

Kata kunci : Anak Usia Sekolah Dasar; Minat Baca; Peran Orang Tua; Tayangan program Televisi

\section{PENDAHULUAN}

Perkembangan teknologi yang semakin pesat menyebabkan semakin mudahnya penyebaran informasi. Informasi dapat diakses oleh masyarakat. Televisi sebagai media informasi elektronik telah melekat pada kehidupan masyarakat kini. Menonton TV telah menjadi live style serta merupakan kebutuhan bagi banyak orang, tentunya sedikit banyak dapat mempengaruhi pikiran bagi penontonnya. Di Indonesia, industri televisi banyak didominasi oleh stasiun-stasiun televisi swasta. Stasiun televisi bersaing untuk mendapatkan penonton setia dengan cara menyajikan program televisi yang banyak menarik minat masyarakat. Persaingan yang cukup ketat dalam meningkatkan rating membuat stasiun televisi menampilkan program tayangan yang hanya mementingkan kebutuhan 'hiburan' daripada 'edukasi'. Sehingga banyak program TV yang tak layak untuk dikonsumsi public khususnya anak usia Sekolah Dasar. Menurut Wulan (1999), anak-anak lebih mudah untuk memahami pesan-pesan yang disampaikan melalui media elektronik audio visual, seperti televisi. Bagi anak-anak usia Sekolag Dasar, menonton televisi merupakan hiburan yang menyenangkan serta mudah dipahami. Tak heran apabila anakanak cenderung meniru apa yang dilihatnya. Program TV yang disajikan saat ini juga sangatlah beragam variatif, oleh karenanya kewajaran saja apabila terdapat semakin besar jumlahnya anak-anak Sekolah Dasar dan orang dewasa yang sangat tertarik menonton televisi (Wulan, 1999). Tak heran apabila TV merupakan media sangat dimanfaatkan sebagai penyebaran informasi. Beberapa contoh program televisi yaitu reality show, infotaiment, talk show, drama, magazine show, news bulletin, current affairs serta lainlainnya.

Peranan orang tua sangat dibutuhkan untuk melaksanakan tindakan mengontrol aktivitas anak. Guna meminimalisir dampak negative dari adanya program TV yang bervariatif, seyogjanya orang tua 
mengajak anaknya untuk melaksanakan aktivitas lain yang bermanfaat serta dapat menambah wawasan anak usia Sekolah Dasar. Kegiatan yang dapat dilakukan untuk menumbuhkan daya kreativitas serta menambah wawasan anak usia Sekolah Dasar adalah membaca. Membaca akan dibutuhkan pada waktu dewasa, jadi akan lebih baik untuk membiasakan anak dalam melakukan aktivitas membaca sejak dini. Membaca dapat membantu untuk mengembangkan pemikiran, meningkatkan pengetahuan, dan memori (Hasriani, 2016). Minat baca perlu dikembangkan khususnya pada anak usia yang sedang dalam usia "golden age", dimana pada usia tersebut anak-anak mengalami masa pertumbuhan daya pikir. Orang tua juga perlu membantu anak dalam memilih program TV yang edukatif serta informative. Program TV Tau Gak Sih bisa dirasakan anak serta orang dewasa.

Menumbuhkan minat baca tidak hanya dengan cara membaca bahan bacaan saja, Melainkan pembelajaran dapat juga dilakukan melalui media audiovual yang dapat menjadi pengalaman baru bagi anak usia sekolah dasar. Media audiovisual merupakan media yang memuat unsur suara dan gambar yang bisa dilihat, sehingga dapat memotivasi anak untuk belajar. (Mursini dalam Edy Suprianto, 2019:24). Oleh karenanya orang tua dapat memanfaatkan program TV yang disukai anak untuk menumbuhkan minat baca anak usia Sekolah Dasar. Misalnya, dengan menonton TV Tau Gak Sih secara tidak langsung anak akan menyerap informasi yang disampaikan. Anakanak juga akan membaca tulisan yang ada dilayar TV sehingga secara tidak langsung anak-anak dapat berlatih membaca melalui tulisan yang ada dilayar. Orang tua dapat mengajak anak, guna menceritakan kembali informasi yang sudah tersampaikan dalam program TV yang telah dilihatnya. Hal tersebut untuk memastikan bahwa anak usia Sekolah Dasar tidak salah dalam menyerap informasi yang telah didapatnya. Apabila informasi yang diserap adalah informasi yang salah, orang tua dapat membenarkannya. Rasanya, aktivitas menonton televisi telah menjadi live style dan melekat erat dalam kehidupan masyarakat. Sehingga stasiun televisi bersaing untuk mendapatkan penonton setia dengan cara menyajikan program televisi yang banyak menarik minat masyarakat. Persaingan yang cukup ketat dalam meningkatkan rating membuat stasiun televisi menampilkan program tayangan yang hanya mementingkan kebutuhan 'hiburan' daripada 'edukasi'. Salah satunya program televisi “Tau Gak Sih?”, dimana bisa dinikmati anak dan orang dewasa. Menumbuhkan minat baca tidak hanya dengan cara membaca bahan bacaan, melainkan orang tua dapat memanfaatkan program TV yang disukai anak untuk menumbuhkembangkan minat membaca anak usia Sekolah Dasar.

Berdasarkan uraian diatas, riset ini bertujuan mendiskripsikan (1). Peranan orang tua untuk menum- 
buhkembangkan minat membaca anak usia Sekolah Dasar dengan melalui program tayangan televisi. (2). Dampak positif dan negatif program TV “Tau Gak Sih” terhadap pengembangan minat baca anak Usia Sekolah Dasar. Pembahasan maupun kajian terhadap minat baca, tidak ada habis-habisnya untuk dibicarakan dan dikaji oleh berbagai ahli engan disiplin ilmu yang saling berbeda. Oleh karenanya kajian dalam penelitian ini membatasi dengan mendayagunakan perspektif sosiologi keluaraga.

\section{METODE PENELITIAN}

\section{A. Obyek Penelitian.}

Research ini berdasarkan terhadap pembahsan dengan memfokuskan pada analisis berbasiskan kajian bersifat komprehensif secara mendetail mengenai content yang sangat urgen dan utama (Bakhtiyar, 2018:79), yakni terhadap peran orang tua dalam pendampingan menonton program tayangan televisi untuk menumbuhkembangkan minat baca anak usia sekolah Dasar. Memahami peranan orang tua untuk menumbuhkembangkan minat membaca anak, sesungguhnya tidak bisa terpisahkan terhadap fungsi keluarga, dimana telah mengalami pergeseran dan perubahan yang sangat pesat. Oleh karenanya orang tua harus bisa melakukan manajemen dalam menumbuhkan minat baca anak usia Sekolah Dasar, terutama melalui media televisi. Mewujudkan budaya baca pada anak usia Sekolah Dasar, sangatlah tidak mudah sebab harus dilakukan melalui proses yang panjang dan melelahkan. Namun usaha untuk meningkatkan minat baca tersebut, tidak boleh dilupakan atau dimarginalkan sebab sangat urgen untuk perkembangan anak di masa usia Sekolah Dasar, terutama demi meraih prestasi kademik secara cemerlang.

\section{B. Ruang Lingkup Penelitian}

Penelitian memiliki ruang lingkup yang tepat dan tidak terlalu bias, dimana penelitian berlingkupkan terhadap aktivitas penganalisaan sangat mendalam dengan berbasis pemfokusan kajian utama (Bakhtiyar, 2017:124), terhadap peranan mengatur minat baca anak usia Sekolah Dasar melalui peranan orang tua untuk melakukan aktivitas mendampingi anak dalam belajar, kususnya menumbuhkembangkan minat baca dengan melalui program tayangan televisi. Mengingat aktivitas menonton televisi telah menjadi gaya hidup masyarakat, karena televisi telah menyajikan berbagai program tayangan yang menarik minat masyarakat. Menumbuhkan minat baca bukan saja dengan membaca bahan bacaan saja. Oleh karenanya orang tua harus mampu untuk bisa memanfaatkan berbagai program TV yang digemari anak guna menumbuhkembangkan minat baca anak usia sekolah Dasar.

\section{Konseptualisasi}

Hakekat manajemen peranan orang tua untuk menumbuhkembangkan minat membaca anak, merupakan 
usaha-usaha maksimal orang tua untuk dapatnya anak berbudaya baca yang tinggi, yang sangat berguna sekali dalam pengembangan anak usia Sekolah Dasar. Adapun tujuannya adalah untuk dapatnya anak meraih prestasi belajar yang baik di sekolah, sehingga anak dalam interaksi sosial tidak mudah minder. Memenej peran orang tua terhadap pengembangan anak bukanlah perkara sepele, sebab berhasil tidaknya anak dalam perkembangannya sangat ditentukan oleh peran tua dalam keluarga.

\section{Pendekatan}

Pada aktivitas penganalisaan dalam riset ini, sangat membutuhkan suatu pemikiran kritis yang memiliki sifat realitis, sehingga bisa mengaplikasikan sesuatu konseptualisasi pada perjalanan historis diwaktu lampau maupun sedang terjadi. Oleh karenanya riset ini sangat baik menggunakan penelitian berjenis historical approach. (Bakhtiyar, 2019:154). Dimana penelitian ini sangat urgen memerlukan penyelidikan berkarakteristika penyelidikan kritis realitis terhadap perkembangan suatu pemikiran. Sumber informasi primer merupakan komponen terpenting yang bisa dipergunakan, sebab dianggap komponen paling utama sebagai data primer. (Bakhtiyar, 2017:369).

\section{E. Metode Penghimpunan Data}

Teknik dalam menghimpun data pada historical approach, dapat mendayagunakan library research secara maksimal, yakni melakukan berbagai kegiatan membaca bermacam-macam literatur yang memiliki subyek bahasan (Bakhtiyar, 2017:75 ), peran orang tua, fungsi keluarga, minat baca dan program tayang TV. Tujuannya tak lain untuk sinkronimasi dan harmonisasi dalam alur pemikiran terhadap berbagai konseptualisasi, yang tertuang dalam wujud analisis data yang bersifat realitis.

\section{F. Analisa Penelitian}

Analisa dilakukan secara diskriptif kualitatif, dengan bertolak dari sumber analisa yang berasal dari bermacam-macam bahan bacaan bersifat sangat teoritik, research serta bukan research. (Bakhtiyar, 2018:119). Agar validitas penelitian bisa tercapai, maka pada penganalisaan sangat membutuhkan pendayagunaan content analysis, yang kegunaannya untuk menganalisa makna terhadap berbagai konsep penting (Bakhtiyar, 2017:33), peranan orang tua, fungsi keluarga dalam menumbuhkembangkan minat baca anak usia Sekolah Dasar melalui program tayangan TV. Observasi pada aktivitas peran orang tua dan fungsi kelurga disetiap harinya, bisa dimanfaatkan sebagai komponen unsur penting dalam menunjang aktivitas pengkontruksian teori. (Bakhtiyar, 2018:69), terutama pada pemaknaan peranan orang tua, fungsi keluarga untuk menumbuhkembangkan minat membaca anak serta progam tayangan TV. Pengembangan minat baca pada anak usia Sekolah Dasar, pada hakekatnya tidak dapat 
terpisahkan dari peran orang tua dan fungsi kelurga sepanjang jaman.

\section{HASIL DAN PEMBAHASAN KAJIAN}

\section{A. Televisi Sebagai Media Pembelajaran}

Televisi merupakan suatu media hiburan serta informasi dengan mengalami perkembangan sangat cepat di Indonesia maupun di dunia (Kuswandi, 1996). Menurut Wikipedia (t.thn), televisi merupakan suatu media telekomunikasi audio visual sebagai penerima siaran gambar. TV bisa diberi pengertian merupakan media komunikasi jarak jauh dengan menggunakan media visual. Dalam Kamus Besar Bahasa Indonesia (dalam Septian, 2016), TV sebagai sistem penyiaran gambar menggunakan suara melewati angkasa, dengan memanfaatkan alat yang bisa merubah cahaya serta bunyi menjadi gelombang listrik, yang kemudian merubahnya kembali menjadi cahaya yang bisa ditonton serta bunyinya bisa didengarkan. Dapat diambil kesimpulan bahwa TV televisi adalah media eletronik audio visual yang digunakan sebagai media komunikasi jarak jauh serta media hiburan. Stasiun televisi merupakan stasiun untuk menyiarkan guna penyebaran siarannya pada bentuk audio serta video ke televisi penerima pada wilayah tertentu. Jika dilihat dari segi cakupannya, terdapat beberapa jenis stasiun televisi, diantaranya adalah stasiun televisi komersial serta stasiun televisi non komersial, stasiun televisi publik, lokal serta nasional (Wikipedia, t.thn).

Setiap stasiun televisi akan menyebarkan siarannya melalui program televisi yang disajikan untuk ditonton oleh masyarakat secara luas. Program acara televisi merupakan media penyampaian informasi serta media hiburan guna menarik audiens agar mereka menonton program acara itu. Maka dari itu, program tayangan TV harus mampu untuk menarik dan mendapatkan minat serta perhatian dari penonton. Program tayangan biasanya dibuat dengan mengikuti trend untuk meningkatkan rating. Menurut Morissan (dalam Septian, 2016) ada dua jenis program TV, yaitu;

1. Program informasi, siaran program acara yang telah dibuat dengan tujuan untuk menambah pengetahuan pada audiens. Program informasi dibedakan atas dua bagian yakni; (1) berita keras (hard news), program berita dengan menyajikan semua informasi penting serta menarik dimana sifatnya segara untuk diketahui oleh masyarakat. Program berita yang termasuk dalam kategori hard news, meliputi straight news, features, serta infotainment. (2) berita lunak (soft news), program berita dimana menyajikan informasi penting serta menarik dengan penyampaian begitu mendalam, tetapi sifatnya tak harus segara ditayangkan. Program berita yang dapat digolongkan pada soft news, 
meliputi current affairs, magazine, documenter, serta talk show.

2. Program hiburan, siaran program acara yang dibuat dengan tujuan untuk menghibur penonton. Program pada kategori hiburan meliputi, game show, program music, pertunjukan, serta program drama.

TV sebagai media pembelajaran pasti memiliki fungsi yang penting untuk meningkatkan minat baca dan minat belajar bagi anak usia sekolah dasar, sebagaimana diungkapkan oleh Sadiman (2009) dalam Friendha Yuanta (2019:92) bahwa media audio visual memiliki fungsi sebagai berikut; (1) memperjelas penyampaian pesan agar tidak bersifat verbalistis, (2) mengurangi keterbatasan ruang, waktu serta daya indra, (3) dapat sebagai solusi mengatasi sifat kepasifan anak usia sekolah dasar. Sedangkan menurut Arsyad (2011) dalam Edy Suprianto (2019:24-25)) bahwa terdapat empat fungsi media pembelajaran, yakni; (1) fungsi atensi yaitu fungsi inti dari media pembelajaran, yang wajib bisa menarik minat serta mengarahkan perhatian supaya dapat melakukan konsentrasi pada materi pelajaran, dengan harapan dapat memperoleh dan mengingat isi pelajaran, (2) fungsi afektif yaitu fungsi yang menggerakkan emosi dan sikap anak usia sekolah dasar terhadap materi yang telah diberikan. (3) fungsi kognitif yaitu fungsi yang dapat memperlancar untuk memahami serta mengingat informasi yang termuat dalam tayangan atau gambar, (4).
Fungsi kompensatoris yaitu fungsi yang diharapkan bisa sebagai alat bantu yang dapat dimanfaatkan anak usia sekolah dasar untuk mempermudah memahami teks, yang selanjutnya mengorganisir informasi agar dapat diingat kembali.

Stasiun TV yang telah menyajikan tayangan informatif dan edukatif yaitu TRANS 7. TRANS 7 (awalnya TV7) mulai dikenal masyarakat secara luas pada tahun 2003. Pada tahun 2006, nama TV diubah menjadi TRANS, namun tetap menggunakan angka 7 (Wikipedia, t.thn). TRANS 7 mempunyai berbagai program bersifat edukasi dan informatif, antara lain si bolang, dunia hewan, si unyil, redaksiana, tau gak sih, dan masih banyak lainnya. Program acara Tau Gak Sih termasuk dalam kategori jenis program current affairs, sebagai program tayangan dengan sajian informasi penting dan muncul sebelumnya serta menarik untuk diulas secara lengkap dan mendalam (Septian, 2016). Tau Gak Sih menyajikan informasi penting dan sangat menarik di lingkuan sekitar, yang seringkali dianggap biasa dan sangat terabaikan serta tidak diketahui oleh umum. Misalnya mengenai makanan khas suatu daerah, sampai dengan makna dari suatu peribahasa.

\section{B. Konseptualisasi Minat Baca}

Menurut Darmono (dalam Hasriani, 2016) minat baca merupakan kemauan yang kuat untuk memotivasi seseorang guna melaksanakan aktivitas membaca. Pada umumnya, pengertian minat 
yaitu cenderungnya hati yang sangat tinggi pada sesuatu, kehendak, keinginan, (Kamus Besar Bahasa Indonesia dalam Hasriani, 2016). Terdapat 2 faktor yang dapat mempengaruhi minat baca, yakni faktor internal adalah berasal pada dalam diri individu serta faktor eksternal adalah berasal dari lingkungan, sebagai contoh motif sosial, ekonomi, lingkungan tempat tinggal, lingkungan sekolah, lingkungan keluarga, dan sebagainya.

Bisa diambil kesimpulan bahwa minat baca adalah kehendak yang berasal dari lubuk hati paling dalam, yang menimbulkan keinginan yang kuat dan mampu memotivasi serta menggerakan seseorang senang melakukan aktivitas membaca bahan bacaan. Kehendak dalam diri seseorang untuk melakukan aktivitas membaca dapat disebabkan oleh faktor eksternal dan internal.

\section{Fungsi Pendidikan Dalam Keluarga.}

Keluarga adalah lingkungan yang pertama kali serta istimewa, bagi anak memperoleh sosialisasi serta internalisasi nilai keagamaan maupun norma sosial dari orang tua. Sebagai lembaga pendidikan yang pertama kali, maka orang tua sangat berperan dalam pendidikan untuk anaknya. Kehidupan anak adalah sebagian besar senantiasa hidup pada lingkungan keluarga, maka pembelajaran yang diperoleh anak paling banyak beradal dari keluarga. Keluarga mempunyai fungsi penting yakni fungsi pada pembentukan watak dan kepribadian anak. Galibnya keluarga berperan sangat besar dalam menunjang pendidikan baik di dalam rumah maupun di sekolah.

Peran orang tua untuk membentuk pribadi serta pembelajaran anak di lingkuan keluarga terdiri atas; (1) Merupakan pengalaman belajar yang pertama kali pada periode kanak-kanak. (2) Memelihara serta menjaga faktor emosional anak. (3) Menginternalisasikan pendidikan moralitas kepada anak. (4) Menanamkan prinsip dasar pendidikan sosial. (5) Memberikan dasar pendidikan keagamaan. (6) Bertanggung jawab untuk memberikan motivasi kesuksesan anak. (7) Memberi kesempatan belajar maupun pengenalan terhadap bermacam-macam ilmu pengetahuan serta keterampilan yang bermanfaat dikemudian hari, sehingga anak memiliki kemampun menjadi manusia mandiri. (8) Memelihara kesehatan anak agar bisa memperoleh kenyamanan dalam melaksanakan proses pembelajaran secara utuh. (9) Memberi kebahagiaan baik dunia maupun akhirat melalui pemberian pendidikan keagamaan sesuai hukum dari Allah SWT, sebagai tujuan terakhir dari manusia. (Bakhtiyar, 2018:39)

D. Program Televisi Berdampak pada Minat Baca Anak Usia Sekolah Dasar

Adanya program acara televisi, sedikit banyak akan mempengaruhi minat baca anak. Dampak dapat dikatakan sebagai akibat/ 
pengaruh dari suatu hal. Dampak program televisi dapat diartikan sebagai akibat yang muncul disebabkan oleh adanya program televisi. Dampak program televisi terhadap minat baca adalah akibat/pengaruh yang muncul disebabkan oleh adanya program acara televisi yang dapat mempengaruhi kebiasaan/keinginan membaca seseorang.

Faktor eksternal dapat mempengaruhi minat baca seseorang. Lingkungan keluarga sebagai lingkungan amat dekat dengan anak, dikarenakan anak menghabiskan sebagian besar waktunya dalam keluarga. Oleh karenanya, peranan orang tua betul-betul diperlukan guna meningkatkan minat baca anak usia Sekolah Dasar dan menimalisir dampak negatif dari program acara televisi. Peran orang tua merupakan keikutsertaan orang tua untuk meningkatkan minat membaca anak di usia Sekolah Dasar. Umumnya anak menjadikan orang tua sebagai contoh. Apabila orang tua ingin mengajari anak, maka orang tua harus mengajari dirinya terlebih dahulu agar anak tidak salah mencontoh perbuatan yang sebaiknya tidak dilakukan.

Begitu pula dengan adanya $\mathrm{TV}$, jika orang tua menjadikan TV merupakan hiburan yang paling utama sehingga akan meletakkan TV pada ruang berkumpul/ruang keluarga, maka tak heran apabila anak akan lebih banyak mengkonsumsi TV. Namun jika orang tua dapat melakukan manajemen waktu menonton TV serta memilihkan anak program TV yang sesuai usia anak dengan bijak, maka dampak negative dari program acara TV dapat diminimalisir. Dalam meningkatkan minat baca, orang tua dapat memanfaatkan TV untuk memotivasi anak Sekolah Dasar dalam menumbuhkan minat membacanya.

\section{E. Peran Pendampingan Orang Tua Dalam Menonton Televisi}

Menonton TV adalah kegiatan yang ringan, sangat mudah, tak mengeluarkan ongkos yang mahal, serta sangat menyenangkan untuk dilakukan khususnya bagi anak-anak usia Sekolah Dasar. Kesenangan dalam menonton televisi sangat cocok terhadap masa perkembangan anak, yang mana anak mempunyai rasa ingin tahu cukup besar serta keinginan untuk bereksplorasi (Wulan, 1999). Dari penelitian sebelumnya, dapat disimpulkan bahwa TV memberi nilai kemanfaatan pada anak, memiliki fungsi hiburan, sumber pengetahuan dan informasi, serta merupakan media edukasi, terutama untuk peningkatan kemampuan kognitif maupun sebagai media belajar social (Partasari dalam Wulan, 1999). Sedangkan Potter dalam Wulan (1999) berpandangan bahwa TV adalah media multi-faceted, artinya terdapat pengaruh positif dan negative. Potter berpendapat sama bahwa program acara TV yang berisikan cerita ataupun drama bisa menstimulasi perubahan kemajuan intelektual, dikarenakan tatkala anak 
menonton televisi anak senantiasa berimajinasi.

Sebenarnya, menonton TV bukan merupakan penyebab utama yang dapat menurunkan minat baca. Kebiasaan membaca bukanlah gaya hidup masyarakat Indonesia, tidak seperti masyarakat-masyarakat di Negara-negara lain yang menjadikan budaya baca menjadi gaya hidup. Yang menjadi permasalahan adalah faktor lingkungan yang menjadikan kebiasaan menonton TV sebagai suatu hal yang penting (Potter dalam Wulan, 1999).

Berdasarkan uraian diatas, dapat disimpulkan bahwa program TV memang berpengaruh kuat pada anak terutama anak usia Sekolah Dasar, apalagi jika anak terlalu sering mengkonsumsi acara-acara TV. Dengan berbagai program acara yang bervariatif, sebaiknya orang tua melakukan pengawasan dan memilihkan program yang sesuai dengan usia anak. Pada kenyataannya, saat ini banyak program acara yang menyajikan informasi serta adegan yang tak layak untuk disuguhkan pada anak usia Sekolah Dasar. Anakanak tidak boleh dibiasakan untuk menonton TV, jadikan menonton TV sebagai hiburan ketika anak-anak bosan dan letih terhadap aktivitasnya. Suguhkan acara yang edukatif bagi anak agar dapat merangsang daya pikir serta menambah wawasan anak di usia Sekolah Dasar, seperti program tayangan Tau Gak Sih.

\section{F. Program Acara Tau Gak Sih dan Aktivitas Membaca Anak}

Program tayangan TV, Tau Gak Sih adalah acara bersifat edukatif, inspiratif, dan informative tayang di TRANS 7 setiap seninjumat pukul 14.15 WIB. Program acara tersebut termasuk dalam jenis program acara current affairs, artinya progam acara yang memberikan informasi berita yang diulas secara lengkap dan mendalam (Septian, 2016). Program tersebut cukup banyak menyita minat dan perhatian, baik bagi anak-anak usia Sekolah Dasar maupun orang dewasa. Program acara tersebut memiliki keunikan tersendiri dalam penyampaian informasi. Informasi yang diulas mengenai hal-hal yang berhubungan dengan kegiatan seharihari, seperti makna dari peribahasa, ketentuan alam, dll. Selain membahas mengenai hal-hal keseharian, informasi yang disampaikan juga membahas mengenai adat, budaya, sampai makanan dan minuman yang berasal dari suatu daerah. Penyampaian informasi juga disampaikan oleh para ahli dengan bahasa yang mudah dipahami oleh masyarakat. Begitu pula dengan pembawa acaranya yang banyak menarik perhatian masyarakat. Pembawa acara secara langsung melakukan tanya jawab dengan masyarakat sekitar mengenai pertanyaan yang diajukan. Dengan gaya lucu serta santai, dipadukan dengan backsound yang menggelitik. Tak heran apabila program acara tersebut mendapati rating $1,5 \%$ 
dengan share 12,2 (Nielsen dalam Nurhalimah, 2017).

Dalam meningkatkan minat baca usia Sekolah Dasar, media TV dapat dijadikan alternative untuk memotivasi anak. Meskipun hubungan antara menonton TV dan aktivitas membaca ini sebenarnya tidak berhubungan, namun jika dikaitkan menonton TV dapat meningkatkan minat baca. Membaca dan menonton televisi merupakan aktivitas yang dilakukan dengan menggunakan indera penglihatan serta pendengaran yang merupakan alat utama. Kedua kegiatan sangat mudah terpengaruh lingkungan disekitarnya. Anak menjadi tak mungkin untuk melakukan aktivitas membaca, jika tidak diajak atau menirukan orang lain di sekitarnya. Begitu pula menonton TV, anak tidak akan melakukannya jika tidak ada faktor yang mempengaruhi (Wulan, 1999). Orang tua adalah faktor yang secara eksternal sangat memberikan pengaruh kuat kepada anak agar melaksanakan kedua aktivitas tersebut. Anak usia Sekolah Dasar banyak menghabiskan sebagian waktunya di rumah, jadi orang tua dapat mengarahkan anak untuk berkembang kea rah yang positif. Salah satunya yaitu dapat memanfaatkan TV untuk memotivasi melakukan kebiasaan membaca.

Riset van der Molen \& van der Voort (dalam Wulan, 1999) membuktikan bahwa anak-anak lebih banyak mengingat pesan-pesan yang disampaikan oleh TV daripada pesan yang disampaikan melalui bacaan.
Belajar membaca tak bisa dilakukan dengan instan, melainkan seseorang wajib melewatinya proses cukup panjang sehingga ia dapat dikatakan mempunyai kemampuan membaca. Menurut Chall, berdasarkan teori kognitif dari Piaget (dalam Thorne dalam Wulan, 1999), mengatakan bahwa terdapat enam tingkatan dalam proses belajar membaca. Level kesatu (disebut pra-membaca), terjadi mulai anak tersebut dilahirkan hingga enam tahun. Level ini, anak akan diperkenalkan pada sesuatu yang sangat melandasi kegiatan baca. Tingkat kedua, terjadi pada usia 6-7 tahun. Tingkat ini disebut awal membaca, dimana anak akan mulai belajar menerjemahkan huruf-huruf menjadi suara/lafal. Tingkat ketiga adalah membaca lancar, terjadi pada anak usia 7-8 tahun. Pada tingkat ini, anak masih dalam tingkat belajar membaca namun ia telah bisa mengidentifikasikan huruf secara cepat. Level keempat, terjadi pada anak usia 9-14 tahun. Dalam tingkatan ini, diharapkan anak sudah dapat memahami arti/makna dari suatu bacaan. Tingkat kelima, terjadi pada usia 14-18 tahun, bacaan yang bersifat sangat kompleks. Level keenam, terjadi pada usia 18 tahun ke atas yaitu konstruksi dan rekonstruksi pandangan terhadap suatu kata.

Jadi, TV dapat dimanfaatkan untuk menarik anak usia Sekolah Dasar untuk melakukan aktivitas membaca. Secara tidak langsung, anak akan membaca tulisan-tulisan yang ada di layar TV. Hal ini dapat dijadikan sarana untuk membantu 
mengajar anak membaca. Pemberian program-program TV dengan bijak pada anak, akan menolong anak dalam belajar untuk membaca. Orang tua harus selektif terhadap tontonan yang ditayangkan TV, sebab anak cenderung untuk meniru sesuatu yang dilihatnya. Siaran yang pantas disuguhkan kepada anak-anak usia Sekolah Dasar yaitu siaran yang dapat mendidik dan tidak menyesatkan serta ramah terhadap public, sehingga dapat disuguhkan kepada semua kalangan. Program TV yang edukatif, informative, dan inspiratif akan memberikan dampak postif terhadap perkembangan anak. Anak usia Sekolah Dasar akan memiliki wawasan yang luas serta dapat memupuk kreatifitasnya melalui program TV yang menyenangkan, ia juga akan tetap terhibur.

Program TV Tau Gak Sih dapat dinikmati untuk ditonton seluruh golongan baik anak-anak usia Sekolah Dasar sampai orang dewasa. Menurut Harold D. Laswell (dalam Rasyid, 2013) mengatakan bahwa media massa memiliki tiga fungsi, yaitu sebagai (1) media informasi dengan menyajikan berbagai informasi yang akurat. (2) media pendidikan, dengan memberikan informasi yang dapat meningkatkan pengetahuan dan penalaran masyarakat. (3) media hiburan, dengan menyajikan berbagai hiburan menarik yang menyegarkan. Secara teori, ketiga fungsi tersebut harus dijalankan dengan seimbang dan berkesinambungan. Menurut penulis,
Tau Gak Sih telah menjalankan fungsi tersebut secara seimbang. Sebagai media informasi, Tau Gak Sih telah menyajikan informasi yang up to date serta akurat yang disampaikan oleh para ahli. Sebagai media pendidikan, Tau Gak Sih menyampaikan informasi mengenai hal-hal yang berhubungan erat kaitannya dengan kehidupan seharihari yang tak pernah terpikirkan oleh masyarakat pada umumnya serta informasi mengenai adat dan budaya pada suatu daerah. Sebagai media hiburan, Tau Gak Sih terbukti sebagai program acara yang banyak menghibur dengan adanya keunikan tersendiri pada setiap episode yang ditampilkan.

Dalam meningkatkan minat baca, program Tau Gak Sih melakukan editing dengan menambahkan tulisan-tulisan pada siarannya. Misalnya dengan memberikan tulisan pertanyaan serta kalimat yang menggelitik. Hal tersebut berhubungan dengan belajar membaca, dengan adanya tulisantulisan pada layar, anak-anak mau tidak mau akan membacanya meski tidak semua dapat memahami dan menafsirkan makna dari tulisan tersebut. Selain itu, program acara Tau Gak Sih dapat dijadikan motivasi untuk meningkatkan minat baca anak usia Sekolah Dasar. Misalnya, dengan pertanyaan yang diajukan oleh pembawa acara, anak termotivasi untuk memperoleh jawaban atas pertanyaan yang sudah ditanyakan. Sehingga, dalam proses menemukan jawaban tersebut, anak-anak akan 
mencari bahan bacaan yang relevan dengan pertanyaan. Setelah melakukan pencarian, anak akan melakukan seleksi terhadap data yang telah diperoleh dengan cara memahami maksud bacaan. Yang terpenting adalah anak usia Sekolah Dasar dapat melatih bacaannya melalui tulisan-tulisan di layar siaran program serta menyerap informasi penting yang disampaikan.

dapat $\begin{gathered}\text { Program acara Tau Gak Sih } \\ \text { memperluas wawasan }\end{gathered}$ penontonnya, khususnya anak-anak di usia Sekolah Dasar. Seperti contoh, setiap pertanyaan yang diajukan akan dijelaskan jawabannya oleh para ahli dan pembawa acara akan diterjemahkan ke dalam bahasa yang sederhana sehingga mudah diserap masyarakat. Lebih dari itu, acara Tau Gak Sih juga menyampaikan pesan yang terkait dengan tindakan yang wajib diamalkan serta perbuatan tak sepatutnya dilakukan, seperti pada tayangan tanggal 25 Oktober 2017 dengan tema "Awas Jangan Suka Main belakang", setelah ahli memberikan jawaban terkait pertanyaan tersebut, dubber akan menjelaskan dengan gaya bahasa yang mudah dipahami dan tidak berat, juga menyisipkan kalimat "wah gak bener ya guys" yang menunjukkan bahwa perbuatan seperti tersebut tidak boleh ditiru. Program acara Tau Gak Sih selalu melakukan shooting di lokasi-lokasi yang berhubungan dengan tema. Misalnya, tema yang diangkat akan membahas mengenai makanan serta adat kota Surabaya, maka shooting akan dilakukan di Surabaya.

\begin{tabular}{llrr}
\multicolumn{2}{c}{ Riset terhadap } & program \\
televisi current affairs. & Current \\
affairs adalah program & dimana \\
memberi sajian informasi berita \\
penting dan diulas secara lengkap
\end{tabular} serta mendalam (Septian, 2016). Adapun stasiun televisi mempunyai program current affairs yaitu TRANS 7. Trans 7 memiliki program televisi yang termasuk dalam jenis current affairs yaitu 'Tau Gak Sih', dimana sebagai program televisi yang bersifat pendidikan serta informatif dengan sajian informasi-informasi kehidupan, dikemas dengan sederhana dan ringan agar mudah untuk diserap dan dimengerti masyarakat. Program tersebut memiliki keunikan tersendiri pada konsep yang diusung, tema yang disajikan pada setiap episodenya mengusung sesuatu dan dianggap sudah biasa serta berlaku umum pada kehidupan keseharian, namun banyak orang yang tidak mengetahui makna dari hal tersebut (Septian, 2016). Dampak positif dari adanya program TV Tau Gak Sih salah satunya yaitu dapat memberikan pengetahuan mengenai berbagai aktivitas yang dikerjakan disetiap hari. Tau Gak Sih dapat memberikan wawasan luas yang disampaikan secara ringan serta mudah untuk dipahami seluruh orang, baik mulai anak-anak usia Sekolah Dasar hingga orang dewasa. Meskipun memiliki dampak positif, tetap saja program TV memiliki dampak negative bagi penikmatnya. Apabila tak bisa melaksanakan untuk memenej waktu sangat dikhawatirkan 
yaitu jika seseorang akan menghabiskan waktunya untuk menonton TV. Seseorang yang terlalu sering menonton TV dapat menurunkan daya pikir dan menghilangkan konsentrasi.

Program acara Tau Gak Sih dapat ditonton semua golongan, sehingga orang tua bisa melakukan pengawasan terhadap program tayangan yang sedang dinikmati anak usia Sekolah Dasar serta turut serta menikmati program tayangan tersebut sebagai media hiburan dan media informasi. Partasari (dalam Hasriani, 2016), dari penelitian yang telah dilakukan disimpulkan bahwa TV telah memberi nilai kemanfaatan pada anak-anak, memiliki fungsi media hiburan, sumber pengetahuan serta informasi. Sebagai media pembelajaran, untuk mengembangkan kemampuan kognitif antara lain untuk peningkatan daya konsentrasi, penguasaan bahasa, matematik ataupun merupakan media social. Adanya program tayangan $\mathrm{TV}$, anak akan bisa belajar beradaptasi terhadap nilai-nilai sosial yang ada pada kehidupan masyarakat serta belajar untuk berperi laku yang tidak bertentangan terhadap norma-norma sosial.

Beberapa dampak positif yang ada, TV tetap akan memiliki dampak negative apalagi jika anak diusia Sekolah Dasar terlalu sering mengkonsumsi TV. Anak yang terlalu sering mengkonsumsi program acara TV akan menghabiskan waktunya dengan menonton TV sehingga menyebabkan anak tidak melakukan aktivitas yang lain. Anak akan cenderungan malas dan akan mengurangi minat belajarnya. Anak berkecenderung untuk meniru terhadap apa saja yang terlihat serta terdengar olehnya, bisa dipastikan apabila ia terus menonton acara TV yang sama secara berulang-ulang, ia akan meniru gaya bahasa serta tingkah laku tokoh-tokoh yang ada di TV. Program acara Tau Gak Sih terdapat kata-kata dengan tujuan menghibur yang sebenarnya dapat berdampak negative terhadap anak. Dalam beberapa episode yang ada, terdapat kata-kata dari pembawa acara yang "menggoda" (dengan tujuan menghibur penonton). Anakanak di usia Sekolah Dasar cenderung tidak dapat membedakan antara kenyataan dan khayalan, mereka dapat saja mencontoh apa yang dilihat dan didengarnya.

Maraknya program acara yang semakin variatif untuk menyita perhatian penonton, terutama anak usia Sekolah Dasar, sehingga orang tua sebaiknya selalu menjalin komunikasi sinergis dengan anak. Komunikasi dilakukan untuk mengarahkan anak agar anak tidak salah mengambil langkah dan meniru tokoh-tokoh yang berperan dalam program tayangan TV. Selain itu, orang tua juga perlu untuk mengatur jadwal menonton TV pada anaknya serta memilihkan program yang sesuai dengan usia anak. Sebaiknya, orang tua memilihkan anak dengan program acara yang dapat digunakan sebagai media pendidikan, media informasi, serta media hiburan bagi 
anak. Lakukan sharing mengenai program tayangan yang telah ditonton anak. Hal ini bertujuan untuk memastikan bahwa anak usia Sekolah Dasar tidak menyerap informasi yang bertentangan dengan nilai-nilai keagamaan serta norma social serta untuk meningkatkan kreativitas dan daya ingat anak. Orang tua dapat mengajarkan anak Sekolah Dasar dengan tidak bergantung pada TV, sesekali anak diajak beraktivitas di luar rumah sebagai contoh mengajak anak ke perpustakaan, ke taman, ke toko buku, dan lainnya. Orang tua juga dapat melatih bacaan anak dengan cara mengarahkan anak untuk membaca tulisan-tulisan yang ada di layar TV.

\section{KESIMPULAN}

(1). Peran orang tua untuk menumbuhkembangkan minat membaca pada anak usia Sekolah dasar adalah; (a). Orang tua wajib mewujudkan terjalinnya komunikasi sinergis dan harmonis dengan anak. (b). Orang tua wajib melakukan komunikasi untuk mengarahkan dan membimbing agar anak tidak salah mengambil langkah dan meniru tokoh-tokoh yang berperan dalam program tayangan TV. (b) .Orang tua perlu untuk memenej jadwal menonton TV serta memilihkan program sesuai dengan usia anak. (d). Orang tua wajib memilihkan program acara yang dapat digunakan sebagai media pendidikan, media informasi, serta media hiburan bagi anak di usia Sekolah Dasar. (e). Orang tua seyogjanya melakukan sharing terhadap program tayangan yang telah ditonton anak, dengan tujuan untuk memastikan anak usia Sekolah Dasar tidak menyerap informasi yang bertentangan dengan nilai-nilai keagamaan, norma social serta meningkatkan kreativitas, daya imajinatif dan daya ingat anak.

(2). Tau Gak Sih sebagai program acara dimana sangat layak untuk ditonton oleh anak usia sekolah Dasar, sebab tayangan berisikan menyampaikan informasi yang memiliki unsur edukasi, informative sehingga dapat meningkatkan wawasan, pengetahuan, serta kreativitas anak. Manfaatkan televisi dari sisi positifnya, seperti memanfaatkan televisi sebagai media belajar dan memperluas pengetahuan maupun untuk mendorong minat baca anak. Program acara sangat menarik sebab melaui adanya audio visual, sehingga bisa dengan mudah dipahami dan diserap informasinya oleh anak. Program acara yang bersifat positif dapat dijadikan sebagai media yang dapat memotivasi anak usia Sekolah Dasar untuk melakukan aktivitas membaca.

\section{DAFTAR PUSTAKA}

Bakhtiyar. (2017). Rekonstruksi Citra dan Eksistensi Perpustakaan : Kajian Peningkatan dan Penguatan Kualitas Perpustakaan Perguruan Tinggi dalam Perspektif Manajemen. LIBRARIA: Jurnal Ilmu Perpustakaan dan Informasi. 7(1), 75-91. DOI: 10.13140RG $>2.2 .11847 .7568$ 
Bakhtiyar (2017). Kiat Sukses Berprofesi Pustakawan Dalam Perspektif Psikologi : Manajemen Intelligence Quotient (IQ) Dan Emotional Quotient (EQ) Dalam Diri Manusia Sebagai Kunci Sukses Berprofesi Pustakawan. INOVASI Jurnal Humaniora, Sains dan Pengajaran, 1(19), 119-133.

DOI:10.13140/RG.2.2.14888.62 720

Bakhtiyar.(2017). Peran Pemimpin Menciptakan Sinergitas Kerja Dalam Pelayanan Publik Bidang Informasi: Pemanfaatan Strategi Komunikasi Guna Mewujudkan Pelayanan Prima Perpustakaan Dalam Perspektif Sosio Politik. Tibanndaru Jurnal Ilmu Perpustakaan dan Informasi. 1 (1), 17-46. DOI: $10.13140 /$

RG.2.2.32924.13444.

Bakhtiyar. (2017). Perilaku Informasi Dalam Perspektif Sosiologi : Suatu Kajian Dalam Sudut Pandang Voluntarism Action Of Theory. Prosising Seminar Nasional "Rekonstruksi Peran Perpustakaan di Era Informasi", 1 (1), 368-378. DOI:

10.13140/RG.2.2.1111.75368.

Bakhtiyar. (2017). Kesiapan dan Persiapan Pustakawan Untuk Berjuang Merebut Dan Merengkuh Kembali Peluang Yang Dianggap Telah Hilang. Tibanndaru Jurnal Ilmu Perpustakaan dan Informasi. 2 (1). DOI:10.13140 /RG. 2.2.21180.08321
Bakhtiyar. (2018), Pembelajaran Berbasis Perpustakaan Sebagai Aspek Kekuatan Utama Mewujudkan Kualitas Prestasi Belajar Siswa : Peran Guru Dalam Pembudayaan Layanan Jasa Informasi Perpustakaan Dari Sudut Pandang Perspektif Sosiologi, INOVASI Jurnal Humaniora, Sains, dan Pengajaran, 20 (2), 112-129.

Bakhtiyar. (2018), Kiat Sukses Meniti Katier Pustakawan : Suatu Kajian Dalam Perspektif Manajemen, Tanggal terbit 2018/1, INOVASI Jurnal Humaniora, Sains, dan Pengajaran, 20 (1), 64-81. DOI:10.13140/RG.2.2.24116.09 607.

Bakhtiyar. (2018). Peran Keluarga Sebagai Pendamping Belajar Anak Dalam Meraih Prestasi Belajar Di Sekoalah Melalui Pemanfaatan Layanan Jasa Informasi Perpustakaan : Suatu Kajian Dalam Perspektif Sosiologi. JPUA Jurnal Perpustakaan Universitas Airlangga. Tanggal terbit 2018/1, 8(1), 37-45.

Bakhtiyar (2019). Public Service Leadership Organization : Work Motivation And Work Productivity In Library Organizations Within Organizational Behavior Perspectives. Equilibrium Jurnal Ekonomi-ManajemenAkutansi. 1 (15).

Hasriani. (2016). Pengaruh Kebiasaan Menonton Televisi Terhadap Minat Baca Siswa Kelas VIII di Perpustakaan 
SMP Negeri 1 Enrekang. http://repositori.uinalauddin.ac.id/2386/1/HASRIA NI.pdf diakses pada 13 April 2020 pukul $13.20 \quad$ WIB.

WikipediA. (2020). https://id.wikipedia.org/wiki/S tasiun_televisi diakses pada tanggal 13 April 2020 pukul $13.00 \mathrm{WIB}$.

WikipediA. (2020) https://id.wikipedia.org/wiki/T elevisi diakses pada tanggal 13 April 2020 pukul 13.00 WIB.

WikipediA. https://id.wikipedia.org/wiki/T rans7 diakses pada tanggal 13 April 2020 pukul 13.30 WIB.

Kuswandi, Wawan. (1996). Komunikasi Massa Sebuah Analisis Media Televisi. Jakarta: Rhineka Cipta

Nurhalimah, Putri. 2017. Efek Kognitif Dan Afektif Program "Tau Gak Sih" di Trans 7 Pada Mahasiswa Fakultas Ilmu Komunikasi Universitas Mercu Buana Angkatan 2014 (Episode "Yuk Kenali Makanan Sehat" tanggal 10 Februari 2016). http://digilib.mercubuana.ac.id /manager/n!@file_skripsi/Isi_ abstract_882722899066.pdf diakses pada tanggal 13 April 2020 pukul 13.30 WIB.

Rasyid, Mochamad Riyanto. (2013). Kekerasan Di Layar Kaca.
Jakarta: Kompas Media Nusantara.

Septian, Tio Tsanihakam. (2016). Flow Of News Acara 'Tau Gak Sih' Di Trans 7. http://repository.fisipuntirta.ac.id/685/ diakses pada 13 April 2020 pukul 13.30 WIB.

Suprianto, Edy. (2019). Implementasi Media Audio Visual untuk Meningkatkan Kemampuan Menulis Teks Ekplanasi. Trapsila: Jurnal Pendidikan Dasar p-ISSN: 2685-7642. EISSN: 2685-8207. Volume 1 Nomor 2 Desember 2019. Halaman 22-32. Surabaya: Jurusan Pendidikan Guru Sekolah Dasar, Fakultas Bahasa dan Sains, Universitas Wijaya Kusuma Surabaya.

Wulan, Ratna. (1999). Nonton Televisi Dan Aktivitas Membaca Pada Anak. Buletin Psikologi, Tahun VII, No. 1 Juni. http:// download. portalgaruda.org/ article.php? article $=369046 \& \mathrm{val}=7990 \&$ tit le $=$ NONTON $\% 20$ TELEVISI \%20DAN\%20AKTIVITAS\% 20MEMBACA $\% 20 P A D A \% 2$ OANAK diakses pada 14 April 2020 14.00 WIB.

Yuanta, Friendha. (2019). Pengembangan Media Video Pembelajaran Ilmu Pengetahuan Sosial Pada Siswa Sekolah Dasar. Trapsila: Jurnal Pendidikan Dasar 1(2) Desember 2019. 91-100. 